Images in...

\title{
Right heart free-floating thrombus after leg injury
}

\author{
Maria Bonou, Konstantinos M Lampropoulos, John Barbetseas
}

Cardiology Department, Polyclinic General Hospital of Athens, Athens, Greece

Correspondence to Dr Konstantinos M Lampropoulos, konlampropoulos@yahoo.gr

\section{DESCRIPTION}

A 70-year-old male patient presented to our hospital for investigation of chest pain. He had a history of muscle injury at the right leg during farm work 10 days earlier. Two dimensional (2D) and three (3D) transthoracic echocardiographic examination visualised enlargement of right heart chambers, with a huge wormlike free-floating thrombus, approximately $7 \mathrm{~cm}$ in length, in them (figure $1 \mathrm{~A}, \mathrm{~B})$. Due to the increased risk of an acute massive pulmonary embolism a full dose of $40 \mathrm{mg}$ of tenecteplase was administered intravenous bolus without delay. In a new transthoracic echocardiographic examination immediately after the fibrinolysis the thrombus had been completely dissolved (figure 1C). B-mode and Doppler ultrasonography of the lower limbs demonstrated residual thrombus in the right popliteal vein (figure 1D) at the region of the muscle injury, while CT scanning revealed evidence of small pulmonary embolism (figure 1E,F). The patient was treated with unfractionated heparin (UFH) initially, which was starting on the first day. Acenocoumarol was added on the second day and UFH was disjunction when international normalised ratio $>2$. Based on guidelines, thrombolysis in acute pulmonary embolism is indicated in cases of haemodynamic instability, cardiogenic shock and persistent arterial hypotension. ${ }^{1}$ However, in case of free-floating right heart thrombus there are insufficient data regarding lytic drugs. The widely used thrombolytic agents in pulmonary embolism are urokinase, streptokinase and recombinant tissue plasminogen activator, while with the short acting tenecteplase the experience is limited. This case presents the usefulness of $2 \mathrm{D}$ and $3 \mathrm{D}$ transthoracic echocardiography in the diagnosis of free-floating right heart thrombi and the potential benefit from the bolus administration of a short acting fibrinolyting agent, in order to eliminate the risk of a massive pulmonary embolism with catastrophic results for the patient.

\section{Competing interests None.}

Patient consent Obtained.

\section{REFERENCES}

1. Torbicki A, Perrier A, Konstantinides S, et al. Guidelines on the diagnosis and management of acute pulmonary embolism: the task force for the diagnosis and management of acute pulmonary embolism of the European Society of Cardiology (ESC). Eur Heart J 2008;29:2276-315.

This pdf has been created automatically from the final edited text and images.

Copyright 2012 BMJ Publishing Group. All rights reserved. For permission to reuse any of this content visit http://group.bmj.com/group/rights-licensing/permissions.

BMJ Case Report Fellows may re-use this article for personal use and teaching without any further permission.

Please cite this article as follows (you will need to access the article online to obtain the date of publication).

Bonou M, Lampropoulos KM, Barbetseas J. Right heart free-floating thrombus after leg injury.

BMJ Case Reports 2012;10.1136/bcr.12.2011.5366, Published XXX

Become a Fellow of BMJ Case Reports today and you can:

- Submit as many cases as you like

- Enjoy fast sympathetic peer review and rapid publication of accepted articles

- Access all the published articles

- Re-use any of the published material for personal use and teaching without further permission

For information on Institutional Fellowships contact consortiasales@bmjgroup.com

Visit casereports.bmj.com for more articles like this and to become a Fellow

Keep up to date with all published cases by signing up for an alert (all we need is your email address) http://casereports.bmj.com/cgi/alerts/etoc 


\section{BMJ Case Reports}

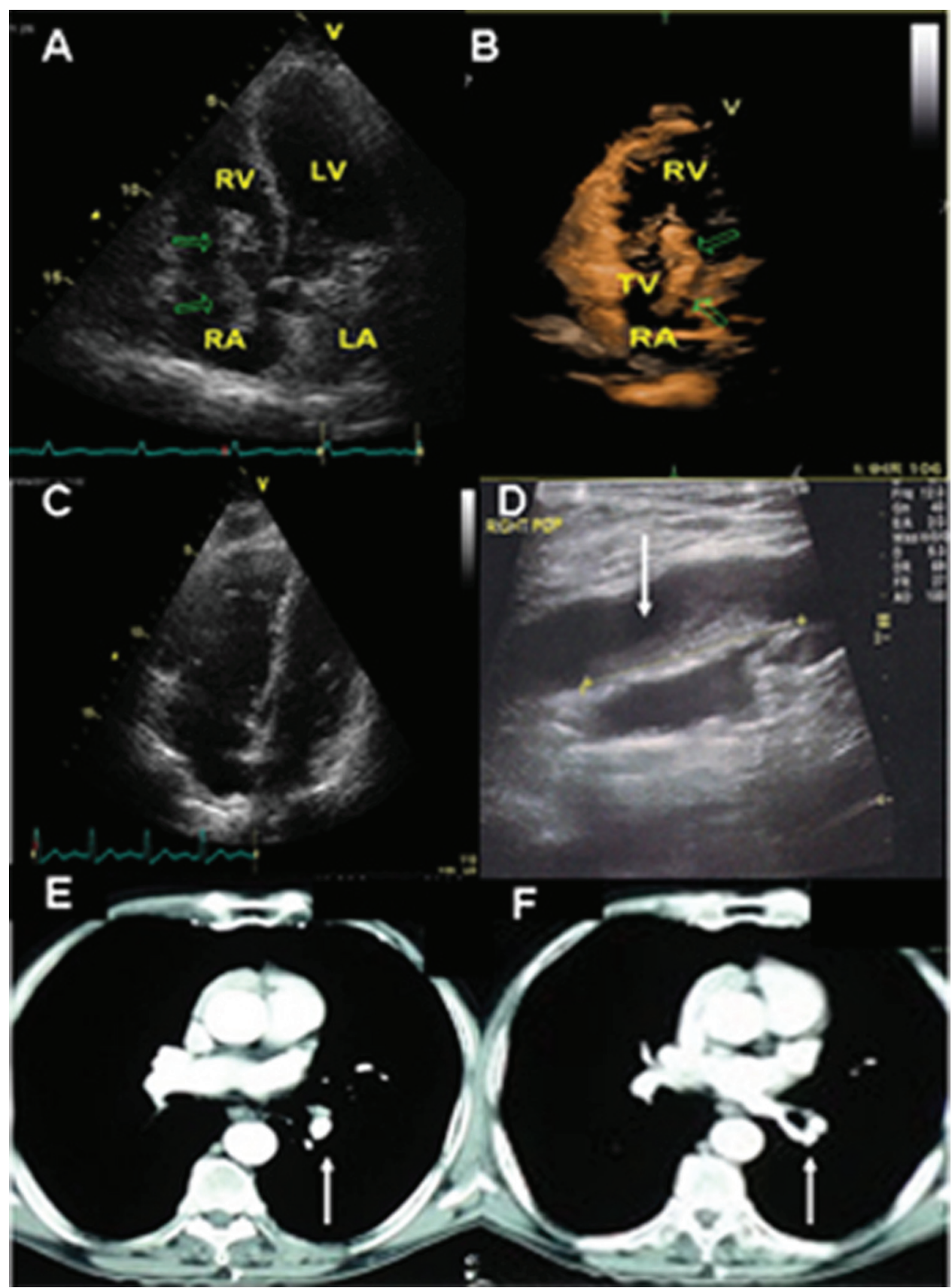

Figure $1(\mathrm{~A}, \mathrm{~B})$ Two dimensional (2D) and three (3D) transthoracic echocardiographic (four chamber view) examination visualised enlargement of right heart champers, with a huge wormlike free-floating thrombus, approximately $7 \mathrm{~cm}$ in length, in them. (C) In a new transthoracic echocardiographic (four chamber view) examination immediately after the fibrinolysis the thrombus had been completely dissolved. (D) B-mode and Doppler ultrasonography of the lower limbs demonstrated residual thrombus in the right popliteal vein. $(E, F) C T$ scanning revealed evidence of small pulmonary embolism. 